e-ISSN: 2686-522X, p-ISSN: 2686-5211

DOI: https://doi.org/10.38035/jafm.v1i5

Received: 04 October 2020, Revised: 13 October 2020, Publish: 04 November 2020 https://creativecommons.org/licenses/by/4.0/

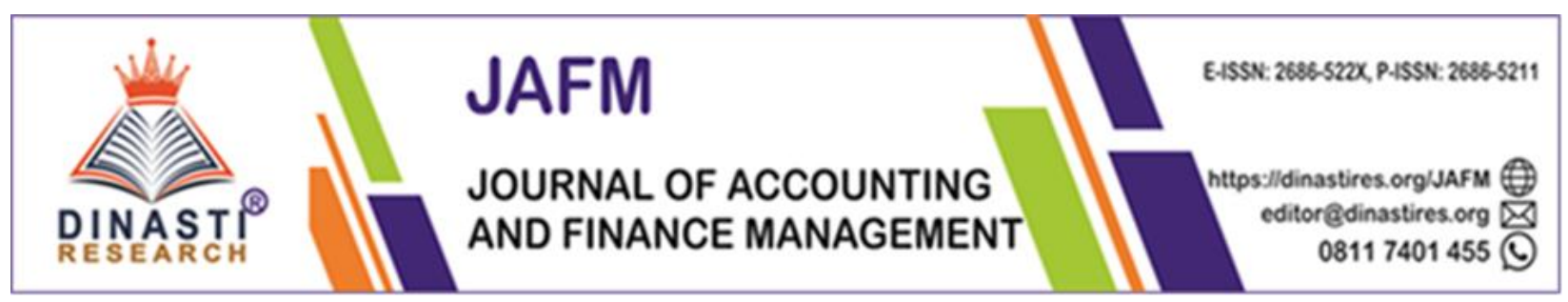

\title{
Model of Brand Image and Purchasing: Price Perceptionand Product Quality (Literature Review of Marketing Management)
}

\author{
Wydyanto ${ }^{1)}$, Andri Yandi ${ }^{2)}$ \\ 1) Ph.D Student, Institute of Visual Informatic, Universiti Kebangsaan Malaysia, Selangor \\ Malaysia,p93043@siswa.ukm.edu.my \\ 2) Faculty of Business and Economic, Universtas Batanghari, Jambi Indonesia, \\ andriyandi.ali@gmail.com
}

Corresponding author: Andri Yandi ${ }^{2}$

\begin{abstract}
Previous research or relevant research is very important in a research or scientific article. Previous research or relevant research serves to strengthen the theory and phenomenon of the relationship or influence between variables. This article reviews the factors that influence brand image and purchasing decision, namely: price perception and product quality, a Marketing Management Literature Study. The results of this research library are that: 1) Price perception has a relationship and affects the brand image; 2) Product quality has a relationship and affects the purchasing decision; 3) Price perception has a relationship and affects the brand image; 4) Product quality has a relationship and affects the purchasing decision, and 5) Brand image has a relationship and affects the purchasing decision.
\end{abstract}

Keywords: Price Perception, Product Quality, Brand Image, Buying Decision

\section{INTRODUCTION}

Students in general at the end of the lecture will be faced with the obligation to make a scientific paper according to their field of knowledge. Students who are able to write scientific papers are considered capable of combining their knowledge and skills in understanding, analyzing, describing, and explaining problems related to the scientific field they take. The scientific work made is a requirement to obtain from most tertiary institutions before taking the final strata one (thesis), postgraduate thesis (S2) in the form of a Thesis, and for undergraduate students (S3) in the form of a Dissertation.

Based on empirical experience, many students have difficulty finding supporting articles 
for their scientific work as previous research or as relevant research. Articles as relevant researchers are needed to strengthen the theory under study, to see the relationship between variables and to build hypotheses, also very much needed in the discussion of research results.

This article is a literacy review in marketing management science, especially discusses the variables: price perception (x1) and product quality (x2), which influence brand image (y1) and purchasing decisions (y2)

Based on the background, problems will be formulated that will be discussed in the literature review article so that it is more focused on literature review and the results and discussion later, namely:

1. Does price perception have a relationship and influence on brand image.

2. Does product quality have a relationship and affect purchasing decisions.

3. Does promotion have a relationship and affect the brand image.

4. Does product quality have a relationship and affect the purchasing decision.

5. Does the brand image have a relationship and influence the purchasing decision.

\section{LITERATURE REVIEW}

\section{Brand image}

According to (McKnight et al., 2002), trust is built between parties who do not know each other either in the interaction or in the transaction process. Meanwhile, according to Gunawan (Gunawan \& Imam, 2013) trust is defined as a form of attitude that shows feelings of like and persist in using a product or brand. (McKnight et al., 2002) state that there are two dimensions of consumer trust, namely:

1. Trusting Belief. State that there are three elements that build trusting belief, namely benevolence, integrity, competence.

2. Trusting Intention. A deliberate thing where a person is ready to depend on others in a situation, this happens personally and leads directly to other people.

Brand Image have been examined extensively by previous researchers including: (Ali etal., 2016), (M \& Ali, 2017), (Ali \& Mappesona, 2016), (Ali, Narulita, et al., 2018a), (Novansa \& Ali, 1926), and (Toto Handiman \& Ali, 2019).

\section{Buying decision}

In more detail, according (Tjiptono \& Fandy, 2008) purchasing decisions are a process where consumers recognize the problem, seek information about a particular product or brand and evaluate how well each of these alternatives can solve the problem, which then leads to a purchase decision. Kotler and Keller (Kotler, Keller, et al., 2012) also describes the stages of the customer decision process Five Stage (Five stage model of the customer buying process),

The dimensions of purchasing decision variables used in this study based on (Kotler, Philip, et al., 2012) are:

1) Product selection. Can make decisions to buy a product or use the money for other purposes. In this case the company must focus its attention on people who are interested in buying a 
product and the alternatives they are considering.

2) Purchase amount. Can make several decisions about how many products to buy and of course according to the needs and desires of consumers.

3) Time of purchase. Consumers make decisions about when to make purchases, this problem concerns their needs, for example: someone buys every day, once a week, even repeatedly.

Buying Decision have been examined extensively by previous researchers including: (Richardo et al., 2020), (Desfiandi, Desfiandi, et al., 2017), (Yunita \& Ali, 2017), (Brata et al., 2017), (Ali, 2019a), (Mappesona et al., 2020), (Ali, 2019a), (Novansa, Hafizh, Ali, 2017), (Sivaram et al., 2020), (Thanh Nguyen et al., 2019), (Ali, Evi, et al., 2018), (Ali, 2019b), (Anggita \& Ali, 2017), (Toto Handiman \& Ali, 2019), and (Ali, Narulita, et al., 2018b).

\section{Price perception}

In theory, according to (Tjiptono \& Fandy, 2008), the price is a monetary unit or other measure (including goods and services) that is exchanged in order to obtain ownership rights or use of a good or service. stated by Buchari Alma (Alma \& Buchari, 2012), whereas according to the expert opinion, Djaslim Saladin (Buchory et al., 2010) suggests that price is a component that generates income while others generate costs.

Price dimension based on According to Kotler and Armstrong translated by Bob Sabran (Kotler, Philip, et al., 2012) explains that there are four measures that characterize price, namely price affordability, price compatibility with product quality, price compatibility with benefits, and price according to ability or price competitiveness can be explained as follows:

1. Price Affordability. can reach the price set by the company.

2. Price match with product quality. As an indicator of quality for consumers, people often choose a higher price between two goods because they see a difference in quality.

3. Price match with benefits. Buy a product if the benefits that are felt are greater or equal to what has been spent to get it.

4. Prices are according to ability or price competitiveness. Often comparing the price of a product with other products, in this case the expensive price of a product is highly considered by consumers when buying the product.

Price Perception have been examined extensively by previous researchers including: (Christina Catur Widayati et al., 2020), and (C.C. Widayati et al., 2020)

\section{Product Quality}

Kotler and Keller in the research product quality is the ability of a product to deliver performance results that match or even exceed what customers expect. There are nine dimensions of product quality according to Kotler and Keller are as follows: form, feature, performance quality, durability, realibility style, design.

In line with the theory, product quality is a product characteristic in the ability to meet the needs that have been determined and latent. This product is defined as anything that can be offered to the market to gain attention, expertise, usefulness, or consumption that meets the wants or needs. 
According to Philip Kotler explains one of the main values that customers expect from suppliers is the high quality of products and services. So from the statement can be stated that the quality of the product can affect consumers in deciding to obtain the product.

which reflects the quality of all dimensions of product offerings that generate benefits for customers. There are eight dimensions of product quality that are considered as attributes of an item evaluated by consumers and will be used in this research, namely: product performance, product features, reliabilities, conformance, durability, service ability, aesthetics, fit and finish.

Product quality variables have been examined extensively by previous researchers including: (Desfiandi, Fionita, et al., 2017), (M \& Ali, 2017), (Ali, Narulita, et al., 2018a), (M \& Ali, 2017), (Ali, Evi, et al., 2018), (Prihartono \& Ali, 2020), (Riyanto et al., 2017), (Maisah \& Ali, 2020), (Brata et al., 2017), (Thanh Nguyen et al., 2019), (Agussalim et al., 2017b), (Ali, 2019b), and (Anggita \& Ali, 2017b)

\section{RESEARCH METHODS}

The method of writing scientific articles is by qualitative methods and literature study or Library Research. Reviewing literature books in accordance with the theory discussed, especially in the scope of Human Resource Management (HRM). Besides, it is reputable scientific articles as well as scientific articles from journals that are not yet reputable. All cited scientific articles are sourced from Mendeley and Google Scholar.

In qualitative research, literature review should be used consistently with methodological assumptions. This means that it must be used inductively so that it does not lead to the questions posed by the researcher. One of the main reasons for conducting qualitative research is that it is explorative in nature (Ali \& Limakrisna, 2013).

Furthermore, it is discussed in depth in the section entitled "Related Literature" or literature review ("Review of Literature"), as a basis for the formulation of hypotheses and will then become the basis for making comparisons with the results or findings revealed in the research. (Ali \& Limakrisna, 2013).

\section{FINDINGS AND DISCUSSION}

Based on the problem formulation and literature review, the discussion of this article is as follows:

\section{The effect of price perception on brand image}

Price perception has a relationship and affects brand image. The better price perception by customers, the better the brand image of the product or company. A brand image is a set of associations about a brand that is stored in the mind or memory of consumers ". There are several factors that influence brand image Schiffman and Kanuk (2007) mention the factors forming a brand image, namely: 1). Quality or quality, relating to the quality of the goods offered by producers with certain brands; 2) Trustworthy or dependable. relating to the opinion or agreement formed by the community about a product that is consumed; 3 ). Uses or benefits associated with the function of a product that can be used by consumers. 4). Price, 
which in this case relates to the high and low or the amount of money spent by consumers to influence a product, can also affect the long-term image; and 5). The image that is owned by the brand itself, namely in the form of views, agreements and information relating to a brand of a particular product.

This is in line with the results of research conducted previously by (Ali et al., 2016), (M \& Ali, 2017), (Ali \& Mappesona, 2016), (Ali, Narulita, et al., 2018a), (Novansa \& Ali, 1926), and (Toto Handiman \& Ali, 2019).

\section{The effect product quality on brand image}

Product quality has a positive and significant effect on brand image. In retail, product quality is divided into, product packaging, after-sales, and product availability / variety. The Product Quality dimension itself consists of: performance, durability, conformance to specifications, features (features), reliability, aesthetics, perceived quality. Brand image is the key to retaining customers (Oliver, 2010), where the dimensions of the brand image are: accessto services, service offered, personal contact, security and reputation. The results of this study are in line with research by Flavian, Torres, and Guinaliu (2004), that there is a significant relationship between Service Quality and Brand Image.

This is in line with the results of research conducted previously by (Desfiandi, Fionita, et al., 2017), (M \& Ali, 2017), (Ali, Narulita, et al., 2018a), (M \& Ali, 2017), (Ali, Evi, et al., 2018), (Prihartono \& Ali, 2020), (Riyanto et al., 2017), (Maisah \& Ali, 2020), (Brata et al.,2017), (Thanh Nguyen et al., 2019), (Agussalim et al., 2017), (Ali, 2019b), and (Anggita \& Ali, 2017). (Christina Catur Widayati et al., 2020), and (C.C. Widayati et al., 2020), Agussalim, 2017).

\section{The effect of price perception on purchasing decisions}

Price perception has an effect on purchasing decisions. The better price perception by customers, the better will be the interest in purchasing decisions.

Price is an element of the marketing mix that is flexible, which can change at any time according to time and place. Prices are not just numbers on the label of a package or store shelf, but prices have many forms and carry out many functions. According to Kotler and Keller (2012:67), price is one element of the marketing mix that generates revenue, another element generates costs. Price is the easiest element in any marketing program to customize, product features, channels, and even communication take a lot of time.

Campbell in Cockril and Goode (2010: 368) states that price perception is a psychological factor from various aspects that has an important influence on consumer reactions to prices. That's why price perception is the reason why someone makes a decision to buy.

This is in line with the results of research conducted previously by (Christina Catur Widayati et al., 2020), (C.C. Widayati et al., 2020), : (Richardo et al., 2020), (Desfiandi, Desfiandi, et al., 2017), (Yunita \& Ali, 2017), (Brata et al., 2017), (Ali, 2019a), (Mappesona et al., 2020), (Ali, 2019a).

\section{The effect of product quality on purchasing decisions}

Product quality affects the purifying decision. Product quality is the physical condition, 
function and characteristics of a product, both goods or services based on the level of quality expected, such as durability, reliability, accuracy, ease of operation, product repair and other product attributes with the aim of meeting and satisfying the needs of consumers or customers.

Product quality is one of the keys to competition among business actors that are offered to consumers. Consumers always want to get quality products according to the price paid, even though there are some people who think that, expensive products are quality products. If this can be done by the company, then the company will still be able to satisfy consumers and be able to increase the number of consumers.

That this research is supported by previous research by (Richardo et al., 2020), (Desfiandi, Desfiandi, et al., 2017), (Yunita \& Ali, 2017), (Brata et al., 2017), (Ali, 2019a), (Mappesona et al., 2020), (Ali, 2019a), (Novansa, Hafizh, Ali, 2017), (Sivaram et al., 2020), (Thanh Nguyen et al., 2019), (Ali, Evi, et al., 2018), (Ali, 2019b), (Anggita \& Ali, 2017), (Toto Handiman \& Ali, 2019), (Ali, Narulita, et al., 2018b).

\section{The effect brand image on purchasing decisions.}

Brand image has a relationship and affects purchasing decisions. The better the brand image is perceived by customers, the better the interest in purchasing decisions will be.

The buying decision is one of the main components of consumer behavior. Consumer purchasing decisions are the step-by-step consumers use when buying goods and services. The purchase decision is a problem-solving approach to human activities to buy goods or services in fulfilling their wants and needs which consists of identifying needs and wants, searching for information, evaluating alternative purchases, purchasing decisions and behavior after purchase (Swastha, 2007).

This is in line with the results of research conducted previously by: (Ikhsani \& Ali, 2017),(Ali, Narulita, et al., 2018b), (Brata et al., 2017), (Ikhsani \& Ali, 2017), (Ali, 2019b), (Yunita \& Ali, 2017), (Mappesona et al., 2020), (Novansa, Hafizh, Ali, 2017), (Sivaram et al., 2020), (Richardo et al., 2020).

\section{CONCEPTUAL FRAMEWORK}

Based on a theoretical study and the relationship between variables, the model or conceptual framework of this article in order to construct a hypothesis is as follows:

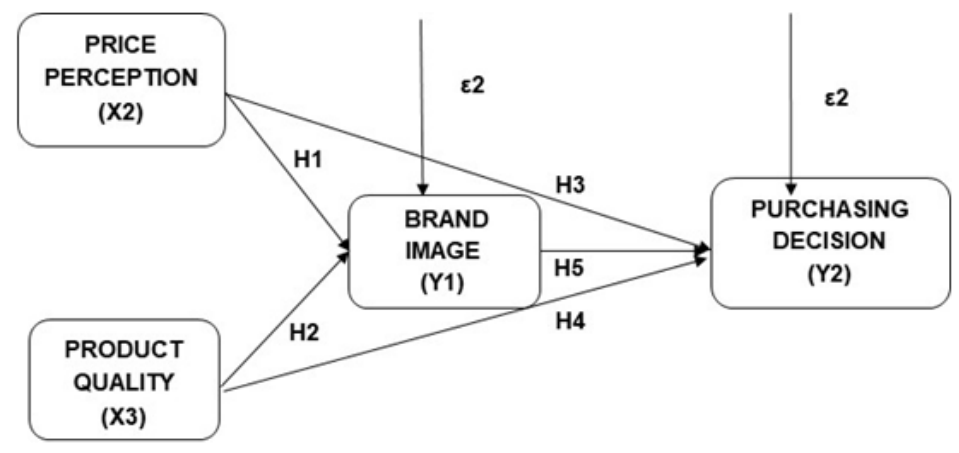

Figure: Conceptual Framework 
Price perception (x1) and product quality (x2) have a relationship and influence on brand image (y1) and purchasing decisions (y2), both directly and indirectly.

Apart from the variables of perception (x1) and product quality (x2) which affect brand image (y1) and purchasing decisions (y2), there are many other variables that interfere with, namely:

1. Customer satisfaction (x2): (M \& Ali, 2017), (Limakrisna \& Ali, 2016), (Ali et al., 2016), (Mappesona et al., 2020), and (Sulistiorini \& Ali, 2017).

2. Promotion (x2): (Ali, Evi, et al., 2018), (Prihartono \& Ali, 2020), (Richardo et al., 2020), (Mappesona et al., 2020), (Sulistiorini \& Ali, 2017), (Hairiyah \& Ali, 2017), (Ali, Narulita, etal., 2018a), and (Brata et al., 2017).

3. Service quality (x3): (M \& Ali, 2017), (Limakrisna \& Ali, 2016), (Yunita \& Ali, 2017), (Yunita \& Ali, 2017), (Ali \& Mappesona, 2016), (Ali, Evi, et al., 2018), (Sitio \& Ali, 2019), and (Anggita \& Ali, 2017)

\section{CONCLUSION AND SUGGESTION Conclusion}

Based on the results and discussion, it can be concluded to build a hypothesis for further researchas below:

1) Price perception has a relationship and affects the brand image.

2) Product quality has a relationship and affects the purchasing decision.

3) Price perception has a relationship and affects the brand image.

4) Product quality has a relationship and affects the purchasing decision, and

5) Brand image has a relationship and affects the purchasing decision.

\section{Suggestion}

Based on the conclusions above, the suggestion in this article is that there are many other factors that influence brand image and purchasing decisions apart from price and promotion, therefore further studies are needed to complement what other factors can influence. brand image and purchasing decision.

\section{BIBLIOGRAPHY}

Abubakar, A. M., \& Ilkan, M. (2016). Impact of online WOM on destination trust and intention to travel: A medical tourism perspective. Journal of Destination Marketing and Management, 5(3), 192-201. https://doi.org/10.1016/j.jdmm.2015.12.005

Agussalim, M., Limakrisna, N., \& Ali, H. (2017). Mutual Funds Performance: Conventional and Sharia Product. International Journal of Economics and Financial Issues.

Ali, H. (2019a). Building Repurchase Intention and Purchase Decision: Brand Awareness and Brand Loyalty Analysis (Case Study Private Label Product in Alfamidi Tangerang). Saudi Journal of Humanities and Social Sciences. https://doi.org/10.36348/sjhss.2019.v04i09.009

Ali, H. (2019b). Purchase Decision and Repurchase Models: Product Quality and Process Analysis (Case Study of House Ownership Credit Financing in Permata Sharia Bank Jakarta). Scholars Bulletin. https://doi.org/10.36348/sb.2019.v05i09.006 
Ali, H., Evi, N., \& Nurmahdi, A. (2018). The Influence of Service Quality , Brand Image and Promotion on Purchase Decision at MCU Eka Hospital. Business and Management Studies. https://doi.org/10.21276/sjbms.2018.3.1.12

Ali, H., Limakrisna, N., \& Jamaluddin, S. (2016). Model of customer satisfaction: The empirical study at Bri in Jambi. International Journal of Applied Business and Economic Research.

Ali, H., \& Mappesona, H. (2016). Build brand image: Analysis Service Quality and Product Quality (case study at Giant Citra Raya). International Journal of Economic Research.

Ali, H., Narulita, E., \& Nurmahdi, A. (2018a). Saudi Journal of Business and Management Studies ( SJBMS ) The Influence of Service Quality, Brand Image and Promotion on Purchase Decision at MCU Eka Hospital. Business and Management Studies. https://doi.org/10.21276/sjbms.2018.3.1.12

Ali, H., Narulita, E., \& Nurmahdi, A. (2018b). The Influence of Service Quality, Brand Image and Promotion on Purchase Decision at MCU Eka Hospital. Saudi Journal of Business and Management Studies. https://doi.org/10.21276/sjbms.2018.3.1.12

Alma, \& Buchari. (2012). Manajemen Pemasaran dan Pemasaran Jasa. Alfabeta.

Anggita, R., \& Ali, H. (2017). The Influence of Product Quality, Service Quality and Price to Purchase Decision of SGM Bunda Milk (Study on PT. Sarihusada Generasi Mahardika Region Jakarta, South Tangerang District). Scholars Bulletin. https://doi.org/10.21276/sb

Brata, B. H., Husani, S., \& Ali, H. (2017). The Importance of Quality Products, Price, Promotion, and Location to Product Purcese Decision on Nitchi At PT. Jaya Swarasa Agung in Central Jakarta. Saudi Journal of Business and Management Studies. https://doi.org/10.21276/sjbms

Buchory, Achmad, H., \& Saladin, D. (2010). Manajemen Pemasaran. Linda Karya.

Desfiandi, A., Desfiandi, A., \& Ali, H. (2017). Composite Stock Price Index (IHSG) Macro Factor in Investment in Stock (Equity Funds). International Journal of Economics and Financial Issues.

Desfiandi, A., Fionita, I., \& Ali, H. (2017). Implementation of the information systems and the creative economy for the competitive advantages on tourism in the province of Lampung. International Journal of Economic Research.

Gunawan, \& Imam. (2013). Metode Penelitian Kualitatif. Bumi Aksara.

Hairiyah, S., \& Ali, H. (2017). Customer Decision Analysis in Taking Multipurpose Loan: Promotions, Locations and Credit Procedures ( A Case of the Bank " PQR Jakarta "). Saudi Journal of Business and Management Studies. https://doi.org/10.21276/sjbms.2017.2.3.6

Ikhsani, K., \& Ali, D. H. (2017). Keputusan Pembelian: Analisis Kualitas Produk, Harga dan Brand Awareness (Studi Kasus Produk Teh Botol Sosro di Giant Mall Permata Tangerang). In Jurnal SWOT.

Kotler, Keller, Philip, \& Lane, K. (2012). Marketing Management. Pearson Pretice Hall, Inc.

Kotler, Philip, \& Armstrong, G. (2010). Principles of Marketing (Edisi 13). Pearson.

Kotler, Philip, \& Armstrong, G. (2012). Principles of Marketing (14th ed). Prentice hall. Kotler,

Philip, \& Armstrong, G. (2014). Principle Of Marketing, 15th edition. New Jersey: Pearson Pretice Hall

Limakrisna, N., \& Ali, H. (2016). Model of Customer Satisfaction: Empirical Study At Fast Food Restaurants in Bandung. International Journal of Business and Commerce.

M, A., \& Ali, H. (2017). MODEL KEPUASAN PELANGGAN: ANALISIS KUALITAS PRODUK DAN KUALITAS LAYANAN TERHADAP CITRA MEREK PADA 
GIANT CITRA RAYA JAKARTA. Jurnal Manajemen. https://doi.org/10.24912/jm.v21i3.254

Maisah, \& Ali, H. (2020). Entrepreneurship culture development process: Implementation of Islamic education values in the Batik Jambi (case study in Seberang Jambi community). Talent Development and Excellence.

Mappesona, H., Ikhsani, K., \& Ali, H. (2020). Customer purchase decision model, supply chain management and customer satisfaction: Product quality and promotion analysis. International Journal of Supply Chain Management.

McKnight, Choudhury, \& Kacmar. (2002). Developing and ValidatingTrust Measures for eCommerce: An Integrative Typology.Information Systems Research. Developing and ValidatingTrust Measures for E-Commerce: An Integrative Typology.Information Systems Research, 3.

Novansa, Hafizh, Ali, H. (2017). Purchase Decision Model: Analysis of Brand Image, Brand Awareness and Price (Case Study SMECO Indonesia SME products). Saudi Journal of Humanities and Social Sciences.

Novansa, H., \& Ali, H. (1926). Purchase Decision Model: Analysis of Brand Image, Brand Awareness and Price (Case Study SMECO Indonesia SME products). Saudi Journal of Humanities and Social Sciences. https://doi.org/10.21276/sjhss

Prihartono, \& Ali, H. (2020). The promises ethics and marketing concept strategy as a competitive advantage on private higher education (A survey on perception of product attributes and promotion mix in Indonesia). Talent Development and Excellence.

Richardo, Hussin, M., Bin Norman, M. H., \& Ali, H. (2020). A student loyalty model: Promotion, products, and registration decision analysis-Case study of griya english fun learning at the tutoring institute in wonosobo central Java. International Journal of Innovation, Creativity and Change.

Riyanto, S., Adila, L., \& Ali, H. (2017). The Effect of Incentives And Job Enthusiasm To Productivity of Go-Jek Driver At PT . Go-Jek Indonesia. Journal of Research in Business and Management.

Sitio, T., \& Ali, H. (2019). Patient Satisfaction Model and Patient Loyalty: Analysis of Service Quality and Facility (Case Study at Rawamangun Special Surgery Hospital). Scholars Bulletin. https://doi.org/10.36348/sb.2019.v05i10.002

Sivaram, M., Munawar, N. A., \& Ali, H. (2020). DETERMINATION OF PURCHASE INTENT DETERMINATION OF PURCHASE INTENTION THROUGH BRAND AWARENESS AND PERCEIVED QUALITY (Case Study: For consumers PT. Sentosa Santosa Finance Tangerang area). Dinasti International Journal of Management Science. https://doi.org/10.31933/dijms.v1i2.71

Sulistiorini, M. S., \& Ali, H. (2017). Customer satisfaction model: Product analysis, price, promotion and distribution (case study at PT Integrasia Utama). International Journal of Applied Business and Economic Research.

Thanh Nguyen, P., Ali, H., \& Agung Hudaya. (2019). MODEL BUYING DECISION AND REPEAT PURCHASE: PRODUCT QUALITY ANALYSIS (Case Study of Bank Permata Syariah Jakarta KPR Financing Customers). Dinasti International Journal of Management Science. https://doi.org/10.31933/dijms.v1i1.29

Tjiptono, \& Fandy. (2008). Manajemen Jasa. Edisi Kedua. CV.AndiOffset.

Toto Handiman, U., \& Ali, H. (2019). The Influence of Brand Knowledge and Brand Relationship On Purchase Decision Through Brand Attachment. In International Journal 
of Business Marketing and Management (IJBMM).

Widayati, C.C., Ali, H., Permana, D., \& Nugroho, A. (2020). The role of destination image on visiting decisions through word of mouth in urban tourism in Yogyakarta. International Journal of Innovation, Creativity and Change, 12(3).

Widayati, Christina Catur, Ali, H., Permana, D., \& Nugroho, A. (2020). The role of destination image on visiting decisions through word of mouth in urban tourism in Yogyakarta. International Journal of Innovation, Creativity and Change.

Yunita, D., \& Ali, H. (2017). Model of Purchasing Decision ( Renting ) of Generator Set: Analysis of Product Quality, Price an Service at PT . Hartekprima Listrindo. Economics, Business and Management. https://doi.org/10.21276/sjebm.2017.4.11.12

Wingate, N. (2019). The Influence of Fake Reviews on Consumer Perceptions of Risks and Purchase Intentions. Journal of Marketing Development and Competitiveness, 13(3), 133144. https://doi.org/10.33423/jmdc.v13i3.2244

Yang, Q., Pang, C., Liu, L., Yen, D. C., \& Michael Tarn, J. (2015). Exploring consumer perceived risk and trust for online payments: An empirical study in China's younger generation. Computers in Human Behavior, 50, 9-24. https://doi.org/10.1016/j.chb.2015.03.058

Yu, C. C., Lin, P. J., \& Chen, C. S. (2013). How brand image, country of origin, and selfcongruity influence internet users' purchase intention. Social Behavior and Personality, 41(4), 599-611. https://doi.org/10.2224/sbp.2013.41.4.599

Zhao, J. Di, Huang, J. S., \& Su, S. (2019). The effects of trust on consumers' continuous purchase intentions in $\mathrm{C} 2 \mathrm{C}$ social commerce: A trust transfer perspective. Journal of Retailing and Consumer Services, 50(January), 42-49. https://doi.org/10.1016/j.jretconser.2019.04.014 